\section{Stake Culture Reduces Foliar Disease and Postharvest Fruit Rot in Tomatoes Grown Under Weekly or Forecaster- generated Fungicide Schedules}

\author{
William H. Tietjen, \\ Winfred P. Cowgill, Jr., ${ }^{2}$ \\ Martha H. Maletta, ${ }^{3}$ \\ Peter J. Nitzsche, ${ }^{4}$ and \\ Stephen A. Johnston ${ }^{5}$
}

Additional INDEX WORds. Lycopersicon esculentum, Alternaria solani, Colletotrichum, chlorothalonil, copper sulfate, disease forecasting, early blight, anthracnose

Summary. The effect of disease forecasting systems and stake or ground culture on foliar and postharvest disease control for tomato (Lycopersicon esculentum) was evalu-

Rutgers Cooperative Extension of Warren County, 165 County Route 519 South, Belvidere, NJ 078231949

Research conducted at the Rutgers Cooperative Extension Snyder Research and Extension Farm, Pittstown NJ and supported by grants from the New Jersey Agricultural Experiment Station Sustainable Program. The cost of publishing this paper was defrayed in part by the payment of page charges. Under postal regulations, this paper therefore must be hereby marked advertisement solely to indicate this fact.

${ }^{1}$ County agricultural agent.

${ }^{2}$ County agricultural agent, Rutgers Cooperative Extension of Hunterdon County, 4 Gauntt Place, Flemington, NJ 08822-9058.

${ }^{3}$ Horticultural consultant, Rutgers Cooperative Extension of Hunterdon County, 4 Gauntt Place, Flemington, NJ 08822-9058.

${ }^{4}$ County agricultural agent, Rutgers Cooperative Extension of Morris County, PO Box 900, Morristown, NJ 07963-0900.

${ }^{5}$ Extension specialist plant pathology, Rutgers University, Rutgers Agricultural Research and Extension Cen ter, 121 Northville Road, Bridgeton, NJ 08302-9499. ated during two growing seasons in northern New Jersey. Foliar disease was reduced and marketable yield increased by stake culture. Percent of postharvest losses, including loss due to anthracnose, was significantly reduced by stake culture. Effectiveness of disease control schedules, weekly or forecaster-generated, was not affected by cultural system. Disease forecasting was shown to have potential for optimizing fungicide use in tomato production by controlling foliar disease and fruit anthracnose with fewer applications than a weekly schedule.

$\mathrm{F}$ ungal diseases are a serious threat to tomato production during the warm, moist conditions typical of New Jersey summers. For example, foliar infections of early blight, caused by Alternaria solani, can cause severe defoliation. Exposed fruit is susceptible to sunburn, sunscald, rain checking and increased fruit decay. Marketable yields are decreased.

Surveys taken in the New York City region reported fruit losses exceeding $23 \%$ during marketing. In a 3 -year study conducted in metropolitan New York, two thirds of fresh market tomato losses at retail and consumer levels were caused by alternaria rot (Alternaria alternata), gray mold rot (Botrytis cinerea), rhizopus soft rot (Rhizopus stolonifer) and bacterial soft rot (Erwinia carotovora) (Ceponis and Butterfield, 1979).

A one-year terminal packinghouse study reported a total loss of $10.4 \%$ of all tomatoes packed for retail distribution in the greater New York metropolitan area (Tietjen, 1981). Parasitic diseases accounted for $90 \%$ of the culls. Losses at the terminal packinghouse varied greatly depending on the source of the tomatoes. Tomatoes from the eastern states suffered the greatest loss (16.5\%). Alternaria rot, bacterial soft rot, and sour rot (Geotrichum candidum) were the predominant causes of parasitic disease loss. Anthracnose (Colletotrichum species) was not a major cause of loss, but did occur in fruit from all production regions.

Fruit anthracnose is of special interest in this study because of its long period between infection and symptom development. Colletotrichum sp., especially C. coccodes, is most commonly associated with fruit anthracnose (Jones 
et al., 1991). This fungus thrives under high moisture conditions, and latent infections can survive on immature fruit between the cuticle and epidermal tissues. Latent infections are activated as the tomato ripens in the field or during marketing. Therefore, control of anthracnose requires fungicide coverage during most of the growing season.

Intensive fungicide spray programs are used by New Jersey tomato producers to control foliar and fruit diseases. Nine to twelve fungicide applications are typically required for a crop maintained on a 7 to $10 \mathrm{~d}$ schedule, beginning 2 weeks after transplanting. Use of a disease forecast system and stake culture might optimize disease control and reduce grower costs and pesticide use. Fresh-market tomato growers in northern New Jersey have been encouraged by New Jersey agricultural professionals to adopt stake culture based on observed benefits to crops, but those benefits have not been documented. This study evaluated the effect of disease forecasting and cultural system on control of foliar disease and fruit rots of tomato. Results related to the cultural system are the focus of this report.

\section{Materials and methods.}

The study was conducted at the Rutgers University, New Jersey Agricultural Experiment Station, Clifford E. and Melda C. Snyder Research and Extension Farm in Pittstown, N.J. Freshmarket tomato 'Celebrity' was grown in single rows on raised beds with black plastic mulch and trickle irrigation under stake or ground culture. Nine and eight treatments were evaluated in 1993 and 1994, respectively. A randomized complete block split plot design with four replications was used in both years. The main plot was cultural treatment; the subplot was fungicide treatment. A subplot consisted of a row of ten plants with a guard plant at each end. Threefoot $(0.92-\mathrm{m})$ alleyways separated plots. Guard rows were established between and outside the treatment rows.

A $15 \mathrm{~N}-6.5 \mathrm{P}-12.5 \mathrm{~K}$ analysis dry fertilizer was applied preplant and incorporated into the Quakertown silt loam (fine-loamy, mixed, mesic, Typic Hapludults) soil at $640 \mathrm{lb} /$ acre (717.4 $\mathrm{kg} \cdot \mathrm{ha}^{-1}$ ) in 1993 and at $267 \mathrm{lb} /$ acre $\left(299.3 \mathrm{~kg} \cdot \mathrm{ha}^{-1}\right)$ in 1994 . Fertigation with a $10 \mathrm{~N}-4.4 \mathrm{P}-8.3 \mathrm{~K}$ analysis liquid fertilizer at $40 \mathrm{gal} / \mathrm{acre}\left(375 \mathrm{~L} \cdot \mathrm{ha}^{-1}\right)$ was done about 1 week after transplanting, when the fruit reached $l$ inch $(2.54 \mathrm{~cm})$ diameter and when the fruit began to ripen in 1994.

Transplants were set in the field on 11 June 1993 and 25 May 1994 using a water wheel transplanter (model 1406; Rain-Flo Irrigation, East Earl, Pa.). A $9 \mathrm{~N}-19.7 \mathrm{P}-12.4 \mathrm{~K}$ analysis soluble fertilizer was added to the transplant water at $0.5 \mathrm{oz} / \mathrm{gal}\left(3.9 \mathrm{~g} \cdot \mathrm{L}^{-1}\right)$ and applied at about $8 \mathrm{fl} \mathrm{oz} /$ plant $(0.24 \mathrm{~L} /$ plant $)$. Spacing was 18 inches $(45.7 \mathrm{~cm})$ between plants within the row and $6 \mathrm{ft}$ ( $1.83 \mathrm{~m}$ ) between rows. Plant population was 4,840 plants/acre (11,960 plants/ha). Stake culture plants were pruned three weeks after transplanting, leaving one axillary shoot below the first flower cluster, and staked and tied using the short-stake cultural system (Garrison, 2000). Ground culture plants were inadvertently pruned as for stake culture in 1993 but not pruned in 1994.

Forecast systems evaluated were: FAST (Forecasting Alternaria Solani on Tomatoes) (Madden et al., 1978); CUFAST, Cornell University adaptation of FAST to New York conditions, (Sandlan and Zitter, 1992); and TOMCAST (Tomato Forecaster) developed in Ontario (Pitblado, 1988). These systems use daily severity values determined by the FAST dew model, which relates hours of leaf wetness and temperature during wetness to disease risk, to generate forecasts. FAST and CUFAST also incorporate the FAST rain model. CUFAST estimates leaf wetness through calculations based on relative humidity and rainfall instead of on-site monitoring with leaf wetness sensors as do FAST and TOM-CAST. Each system, as originally developed, uses specific decision thresholds-critical cumulative total severity values-to generate the forecast and resulting spray schedule. The Snyder Farm trials evaluated the systems using either the original thresholds or modified thresholds.

In 1993, there were nine disease control treatments including an untreated control. For six treatments, chlorothalonil (Bravo 720, ISK Biosciences, Mentor, Ohio) at $1.5 \mathrm{lb} /$ acre $\left(1.7 \mathrm{~kg} \cdot \mathrm{ha}^{-1}\right)$ a.i. was applied according to the following schedules: 1) weekly beginning 2 weeks after transplant; 2 ) FAST, original thresholds; 3 ) CUFAST 2 , original thresholds; 4) TOM-CAST, original thresholds of $\mathbf{3 5}$ for fungicide spray initiation and 20 for respray; 5 ) TOM-CAST, modified, 35 and 15 for respray; 6) TOM-CAST modified, 35 and 25 for respray. For two disease control treatments, tribasic copper sulfate at $0.6 \mathrm{lb} / \mathrm{acre}\left(0.7 \mathrm{~kg} \cdot \mathrm{ha}^{-1}\right)$ a.i. with sulfur at $3.9 \mathrm{lb} /$ acre $\left(4.4 \mathrm{~kg} \cdot \mathrm{ha}^{-1}\right)$ a.i. (TopCop, Helena Chemical Company, Memphis, Tenn.) was applied 7) weekly beginning 2 weeks from transplant or 8 ) according to CUFAST 2 . In 1994, there were eight disease control treatments including an untreated control. For seven treatments, chlorothalonil (Bravo 720) at $1.5 \mathrm{lb} /$ acre a.i. was applied according to the following schedules: 1) weekly beginning 2 weeks after transplant; 2 ) FAST, original; 3 ) CUFAST 1 , modified, initiated at first occurrence of dew model; 4) CUFAST 2, original; 5,6,7) the same versions of TOM-CAST used in 1993. Fungicide applications were made with a backpack airblast sprayer delivering $80 \mathrm{gal} /$ acre $\left(750 \mathrm{~L} \cdot \mathrm{ha}^{-1}\right)$. Weather data for generating disease forecasts was collected on site with a Campbell 21X data logger (Campbell Scientific, Logan, Utah).

Foliar disease was rated weekly, beginning with the first appearance of disease in the plots, by visually estimating the percent necrotic foliage in the plot according to the Cooperative State Research Service/National Agricultural Pesticide Impact Assessment Program six class scale (Dillard et al., 1997). Fruit showing at least some overall pink was harvested weekly from 18 Aug. to 29 Sept. 1993 and from 9 Aug. to 27 Sept. 1994, graded for size and marketable quality -2.5 inches $(6.4 \mathrm{~cm})$ or larger diameter, uniform shape and color, free of defects-and weighed. Up to $25 \mathrm{lb}$ $(11.34 \mathrm{~kg})$ of randomly selected marketable fruit was stored for $6 \mathrm{~d}$ at $70^{\circ} \mathrm{F}$ $\left(21.1^{\circ} \mathrm{C}\right)$ in 1993 and $60^{\circ} \mathrm{F}\left(15.6^{\circ} \mathrm{C}\right)$ in 1994 and evaluated for decay development. Decayed fruit were identified visually and counted (1993) and weighed (1993 and 1994). Anthracnose affected fruit were distinguished from other decayed fruit by visible symptoms.

All data were subjected to appropriate analysis of variance using SuperANOVA (Abacus Concepts) or SAS Statistical Program (SAS Institute, Cary, N.C.).

\section{Results and discussion}

The most prevalent foliar fungal diseases were early blight and septoria leaf spot (caused by Septoria lycopersici) in both years. There was significant interaction between 1993 and 1994 for foliar disease rating; all results are presented by year. There were no significant cultural system $\times$ disease control 
Table 1. Effect of disease control treatment on foliar disease and postharvest loss of fresh market tomato.

\begin{tabular}{|c|c|c|c|c|c|}
\hline Treatment & \multicolumn{2}{|c|}{$\begin{array}{c}\text { Fungicide } \\
\text { applications } \\
\text { (no.) }\end{array}$} & \multicolumn{2}{|c|}{$\begin{array}{l}\text { Foliar } \\
\text { disease } \\
\text { rating }^{\mathrm{zy}}\end{array}$} & $\begin{array}{c}\text { Postharvest } \\
\text { loss due to } \\
\text { anthracnose } \\
(\%)^{\mathrm{w}} \\
1994\end{array}$ \\
\hline Untreated control & 0 & 0 & $3.9 \mathrm{~b}$ & $5.4 \mathrm{e}$ & $26.3 \mathrm{c}$ \\
\hline Chlorothalonil weekly & 14 & 14 & $3.0 \mathrm{a}$ & $3.3 \mathrm{a}$ & $5.0 \mathrm{a}$ \\
\hline Chlorothalonil CUFAST 2 & 7 & 10 & $2.9 \mathrm{a}$ & $3.6 \mathrm{abc}$ & $8.3 \mathrm{ab}$ \\
\hline Chlorothalonil TOM-CAST 15 & 2 & 6 & $4.0 \mathrm{~b}$ & $3.8 \mathrm{bc}$ & $22.1 \mathrm{c}$ \\
\hline Chlorothalonil TOM-CAST 20 & 1 & 5 & $3.9 \mathrm{~b}$ & $4.0 \mathrm{~cd}$ & $20.5 \mathrm{bc}$ \\
\hline Chlorothalonil TOM-CAST 25 & 1 & 3 & $3.6 \mathrm{~b}$ & $3.9 \mathrm{c}$ & $17.2 \mathrm{abc}$ \\
\hline Tribasic copper sulfate and sulfur weekly & 14 & --- & $2.9 \mathrm{a}$ & --- & --- \\
\hline
\end{tabular}

${ }^{\mathrm{z}}$ Mean separation in column by Fisher's LSD, $P=0.05$; means followed by the same letter are not significantly different.

VVisual rating of percent necrotic foliage ( 27 Sept. 1993,22 Sept. 1994) using disease severity class scale: $1=0 \%, 2=\geq 1 \% \leq 10 \%, 3=>10 \% \leq 30 \%, 4=>30 \% \leq 70 \%, 5=>70 \%$ $\leq 90 \%, 6=>90 \% \leq 100 \%$ (Dillard et al., 1997).

${ }^{x}$ Mean separation by pair comparisons of least square means from SAS, $P=0.05$; LSD varied with sample size. Means followed by the same letter are not significantly different. wBy weight of decayed fruit.

vTreatment not included in this year.

treatment interactions in 1993 or 1994 for foliar disease rating, total and marketable yield, postharvest loss and, in 1994, for loss due to anthracnose.

In 1993, the weekly and CUFAST 2 treatments significantly reduced foliar disease compared to the untreated control (Table 1). The CUFAST schedule required half the number of sprays of the weekly schedule. There was no significant effect of disease control treatment on total yield or total postharvest loss (data not presented) or on marketable yield or percent marketable yield (Table 2). Below normal rainfall and location of plots in a field with no recent solanaceous crop history contributed to low disease pressure in 1993. In 1994, all disease control treatments reduced foliar disease compared to the untreated control (Table 1). CUFAST treatments requiring 10 or 11 sprays were as effective as the weekly treatments that required 14 sprays. Other treatments reduced foliar disease compared to the untreated control with as few as three sprays. FAST, CUFAST and TOMCAST 25 treatments controlled anthracnose as well as weekly treatments but required as few as three sprays (Table 1 ). Marketable yield and percent marketable yield were increased by all treat- ments compared to the untreated control (Table 2). There were no differences among the TOM-CAST treatments for foliar disease control, anthracnose control, marketable yield or percent marketable yield (Tables 1 and 2).

These results suggested that foliar disease and fruit anthracnose can be controlled in northern New Jersey with fungicides applied according to forecaster generated schedules requiring fewer sprays than weekly schedules. This finding is supported by research results from other areas of the United States (Fulling, 1995; Gleesonetal., 1995; Keinath andDuBose, 1996; Louws et al., 1996).

Table 2. Effect of disease control treatment on marketable yield of fresh market tomato.

\begin{tabular}{|c|c|c|c|c|c|c|}
\hline Untreated control & 0 & 0 & 11.3 & $18.2 \mathrm{a}$ & 43.3 & 38.8 a \\
\hline Chlorothalonil weekly & 14 & 14 & 12.6 & $27.5 \mathrm{c}$ & 49.2 & $52.3 \mathrm{bc}$ \\
\hline Chlorothalonil FAST & 2 & 5 & 13.7 & $23.0 \mathrm{~b}$ & 51.4 & $48.9 \mathrm{~b}$ \\
\hline Chlorothalonil CUFAST 2 & 7 & 10 & 10.7 & $26.3 \mathrm{c}$ & 45.5 & $55.4 \mathrm{c}$ \\
\hline Chlorothalonil TOM-CAST 15 & 2 & 6 & 11.9 & $25.6 \mathrm{bc}$ & 49.6 & $49.5 \mathrm{~b}$ \\
\hline Chlorothalonil TOM-CAST 20 & 1 & 5 & 10.4 & $23.0 \mathrm{~b}$ & 43.2 & $48.7 \mathrm{~b}$ \\
\hline Chlorothalonil TOM-CAST 25 & 1 & 3 & 8.9 & $25.5 \mathrm{bc}$ & 39.1 & $49.4 \mathrm{~b}$ \\
\hline Tribasic copper sulfate and sulfur weekly and sulfur weekly & 14 & --- & 10.6 & --- & 43.1 & \\
\hline Tribasic copper sulfate and sulfur CUFAST 2 & 7 & --- & 10.7 & --- & 46.2 & \\
\hline
\end{tabular}

${ }^{\mathrm{z}}$ Means separation in columns by Fisher's LSD, $P=0.05$; means followed by the same letter are not significantly different.

"Fruit $\geq 2.5$ inches $(6.4 \mathrm{~cm})$ diameter, uniform shape and free of defects.

${ }^{\mathrm{x}} 1.0$ ton/acre $=2.24 \mathrm{t} \cdot \mathrm{ha}^{-1}$.

wBy weight of total yield.

${ }^{v}$ Treatment not included in this year. 
Table 3. Effect of culture on foliar disease, yield and postharvest loss of fresh market tomato.

\begin{tabular}{|c|c|c|c|c|c|c|c|c|c|}
\hline $\begin{array}{l}\text { Cultural } \\
\text { system }\end{array}$ & \multicolumn{2}{|c|}{$\begin{array}{l}\text { Foliar } \\
\text { disease } \\
\text { rating }^{z y}\end{array}$} & \multicolumn{2}{|c|}{$\begin{array}{c}\text { Marketable } \\
\text { yield }^{\text {zx }} \\
\text { (ton/acre) }^{w}\end{array}$} & \multicolumn{2}{|c|}{$\begin{array}{c}\text { Marketable } \\
\text { yield }^{\mathrm{z}} \\
(\%)^{\mathbf{v}}\end{array}$} & \multicolumn{2}{|c|}{$\begin{array}{c}\text { Postharvest } \\
\text { loss }^{\text {ut }} \\
(\%)^{s} \\
\end{array}$} & $\begin{array}{c}\text { Postharvest } \\
\text { loss due to } \\
\text { anthracnose } \\
(\%)^{\mathbf{r}} \\
1994\end{array}$ \\
\hline Ground & $4.0 \mathrm{~b}$ & $4.3 \mathrm{~b}$ & 9.5 & $21.9 \mathrm{a}$ & $38.5 \mathrm{a}$ & $42.6 \mathrm{a}$ & $25.0 \mathrm{~b}$ & $34.1 \mathrm{~b}$ & $30.1 \mathrm{~b}$ \\
\hline Stake & $2.7 \mathrm{a}$ & $3.6 \mathrm{a}$ & 12.9 & $26.9 \mathrm{~b}$ & $52.7 \mathrm{~b}$ & $55.9 \mathrm{~b}$ & $15.2 \mathrm{a}$ & $10.1 \mathrm{a}$ & $6.6 \mathrm{a}$ \\
\hline
\end{tabular}

${ }^{\mathrm{z}}$ Mean separation in column by Fisher's LSD, $P=0.05$; means followed by the same letter are not significantly different.

Visual rating of percent necrotic foliage ( 27 Sept. 1993,22 Sept. 1994$)$ using disease severity class scale: $1=0 \%, 2=\geq 1 \% \leq 10 \%, 3=>10 \% \leq 30 \%, 4=>30 \% \leq 70 \%, 5=>$ $70 \% \leq 90 \%, 6=>90 \% \leq 100 \%$ (Dillard et al., 1997).

${ }^{x}$ Fruit $\geq 2.5$ inches $(6.4 \mathrm{~cm})$ diameter, uniform shape, free of defects.

${ }^{\mathrm{w}} 1.0$ ton $/$ acre $=2.24 \mathrm{t} \cdot \mathrm{ha}^{-1}$.

"By weight of total yield.

uDue to all causes.

${ }^{\mathrm{t}}$ Mean separation by pair comparisons of least square means from SAS, $P=0.05$; LSD varied with sample size. Means followed by the same letter are not significantly different. ${ }^{s}$ By weight of marketable fruit stored postharvest.

${ }^{r}$ By weight of decayed fruit.

There was no significant difference in total yield between cultural systems in either year (data not presented). The inadvertent pruning of ground culture plants in 1993 apparently had no effect on total yield. Marketable yield from stake culture plots was significantly higher than from ground culture plots in 1994, and percent marketable yield was significantly higher from stake culture plots than ground culture plots in both years (Table 3 ). The increase in percent marketable yield with stake culture was $31 \%$ in 1993 and $37 \%$ in 1994. Foliar disease and percent postharvest loss during storage were significantly lower for stake culture than ground culture in both years (Table 3 ). The reduction in percent postharvest losses with stake culture was $40 \%$ in 1993 and $70 \%$ in 1994. Stake culture also significantly reduced postharvest loss due to anthracnose fruit rot in 1994 (Table 3 ).

Increased marketable yields from staked treatments can be attributed to fewer fruit culled for various physical and physiological defects including growth cracks, rain check, catface, zippering, large blossom scars and yellow shoulder. Few fruit in both years were culled because of visible disease.

Reduction in foliar disease and postharvest losses due to anthracnose with staking may be attributed to improved air circulation around plants reducing the high moisture conditions conducive to disease development. Early blight development is directly influenced by daily hours ofleaf wetness (Madden etal., 1978). The anthracnose fruit rot organism also thrives underhigh moisture(Dillard, 1989).Fungicide coverage of staked plants may be more thorough, providing better control of these diseases.
Most postharvest decays are incited by pathogens that enter fruit through an injury or surface defect, e.g., minute cracks and weather checking. Significantreductions in postharvest fruit loss with stake culture compared to ground culture may be attributed to improved fruit cover that decreases weather checking and cracking of fruit (Jones et al., 1991) thus decreasing infection sites. Staking may also decrease these decays by reducing soil contact with fruit, thereby reducing potential decay organism inoculum on the fruit surface. Cleaner fruit may be less subject to abrasion during harvest and initial postharvest grading and packing.

This study clearly demonstrated the benefits of stake culture for fresh market tomato production. Foliar disease damage and postharvest storage loss can be reduced and marketable yield increased by staking. In years when disease potential is high, as in 1994 , anthracnose loss can be decreased by staking. In 1994, staking reduced anthracnose loss to a percentage comparable to loss with the weekly fungicide schedule. Staking can be a valuable disease management practice in conjunction with conventional or forecastergenerated disease control schedules.

\section{Literature cited}

Ceponis, M.J. and J.E. Butterfield. 1979. Losses in fresh tomatoes at the retail and consumer levels in the greater New York area. J. Amer. Soc. Hort. Sci. 104:751-754.

Dillard, H.R. 1989. Effect of temperature, wetness duration, and inoculum density on infection and lesion development of Colletotrichum coccodes on tomato fruit. Phytopathology 79:1063-1066.

Dillard, H.R., S.A. Johnston, A.C. Cobb, and
G.H. Hamilton. 1997. An assessment of fungicide benefits for the control of fungal diseases of processing tomatoes in New York and New Jersey. Plant Dis. 81:677-681.

Fulling , B.A., 1995. Integration of host resistance and weather-based fungicide scheduling for control of anthracnose of tomato fruit. Plant Dis. 79:228-233.

Garrison, S.A. (ed.). 2000. Commercial vegetable production recommendations. N.J. Agr. Expt. Sta. Publ. E001P.

Gleeson, M.L., A.A. MacNab, R.E. Pitblado, M.D. Ricker, D.A. East, and R.X. Latin. 1995. Disease-warning systems for processing tomatoes in eastern North America: Are we there yet? Plant Dis. 79:113-121.

Jones, J.B., J.P. Jones, R.E. Stall, and T.A. Zitter (eds.). 1991. Compendium of tomato diseases. Amer. Phytopathol. Soc.

Keinath, A.P. and V.A. DuBose. 1996. Efficacy and economics of three fungicide application schedules for early blight control and yield of fresh-market tomato. Plant Dis. 80:1277-1282.

Louws, F.J., M.K. Hausbeck, M.K. Kelly and C.T. Stephens. 1996. Impact of reduced fungicide and tillage on foliar blight, fruit rot, and yield of processing tomatoes. Plant Dis. 80:12511256.

Madden, L., S.P. Pennypacker, and A.A. MacNab. 1978. FAST, a forecast system for Alternaria solani on tomato. Phytopathology 68:13541358.

Pitblado, R.E. 1988. Development of a weathertimed fungicide spray program for field tomatoes. Can. J. Plant Pathol. 10:371.

Sandlan, K.P. and T.A. Zitter. 1992. Scheduling fungicide sprays to control tomato early blight using a modified FAST forecasting program. Plant Pathol. Ext. Rpt. 89-3.

Tietjen, W.H. 1981. Losses incurred during marketing of fresh tomatoes in the greater New York area. Proc. 3rd Tomato Qual. Workshop:141-146. 